\title{
EFFECT OF FINANCIAL INCLUSION ON FINANCIAL STABILITY: COUNTRYS BY INCOME LEVEL CLASIFFICATION, 2004-2014
}

\author{
Wirdatul Aini ${ }^{1}$, A. Tony Prasetiantono ${ }^{2}$, \\ ${ }^{1,2}$ Universitas Gadjah Mada, Ulaksumur Caturtunggal Sleman, Yogyakarta, Indonesia \\ Email: aini.wirda@yahoo.com
}

\begin{abstract}
Article History
Received: 12-01-2020

Revision: 24-04-2020

Accepted: 04-09-2020

Published: 05-09-2020

Abstract. Financial inclusion has become a main key for financial service development yet this development should also consider financial stability. The Asian financial crisis 1997 and the Global financial crisis 2008 gave us lesson of how important to maintain financial stability. Thus, the development of the financial services sector through financial inclusion is expected to impact the financial stability of the countries income levels. This study aims to determine the effect of financial inclusion relation to the financial stability in many countries based on their level of income during 2004-2014. This study used unbalanced panel data regression with fixed effect model. The results showed that financial inclusion proxied by commercial bank outstanding deposit has positive yet unsignignificant effect on financial stability for high income and upper-middle income countries, and has negative significant effect for lowermiddle income and low income countries. Meanwhile, financial inclusion proxied by commercial bank outstanding loan has negative significant effect on financial stability in high income and upper middle income countries. This result is the opposite of lower-middle income which showed positive yet unsignificant effect, and positive significant impact for low income countries
\end{abstract}

Keywords: Financial Inclusion, Financial Stability, Financial Crisis, Liquid Assets

\begin{abstract}
Abstrak. Inklusi keuangan menjadi kunci bagi pengembangan sektor jasa keuangan. Pengembangan sektor jasa keuangan harus diikuti dengan stabilitas keuangan yang terjaga. Krisis keuangan Asia dan Global memberikan pelajaran bahwa pentingnya menjaga stabilitas keuangan. Pengembangan sektor jasa keuangan melalui inklusi keuangan diharapkan dapat memberikan pengaruh terhadap stabilitas keuangan antar negara tingkat pendapatan. Penelitian ini bertujuan untuk mengetahui pengaruh hubungan inklusi keuangan terhadap stabilitas sistem keuangan pada berbagai negara berdasarkan kategori tingkat pendapatan pada periode 2004-2014. Penelitian ini menggunakan regresi unbalanced panel data dengan model fixed effect. Hasil penelitian menunjukkan bahwa inklusi keuangan melalui proksi outstanding deposits berpengaruh positif dan tidak signifikan terhadap stabilitas keuangan pada negara berpendapatan tinggi dan menengah ke atas, dan berpengaruh negatif dan signifikan pada pada negara berpendapatan menengah ke bawah dan rendah Sementara itu, melalui proksi outstanding loans berpengaruh negatif dan signifikan terhadap stabilitas keuangan pada negara berpendapatan tinggi dan menengah ke atas, berpengaruh positif dan tidak signifikan pada negara berpendapatan menengah ke bawah, dan berpengaruh positif dan signifikan pada negara berpendapatan rendah. Kata Kunci:
\end{abstract}

Kata Kunci: Inklusi Keuangan, Stabilitas Keuangan, Krisis Keuangan, Aset Lancar

How to Cite: Aini, W \& Prasetiantono, T. (2020). Effect of Financial Inclusion on Financial Stability: Countrys by Income Level Clasiffication, 2004-2014. Indo-Fintech Intellectuals: Journal of Economics and Business, 1 (1), 11-22. http://doi.org/10.54373/ifijeb.v1i1.10 


\section{INTRODUCTION}

Financial inclusion is an important global agenda. International Organization like the G201, IMF2, CGAP, APEC3, World Bank, ADB4, AFI5, OECD6, and others is now focusing its activities on financial inclusion to support economic development globally. Financial inclusion has been applied to various countries, both high-income countries, middle to upper, lower middle income countries (lower middle income countries), and low (low income countries). Financial inclusion very important in supporting economic and social development, where is expected to increase financial stability and growth. This reason which makes the high interest of various countries to implement and make financial inclusion as a strategy to drive growth. The 2008 global crisis provides lessons on the importance of reducing systemic risk and maintaining financial stability. At the same time, country development is promoting financial inclusion as part of economic development (Morgan and Pontines, 2014: 3; Amatus and Alireza, 2015: 40). This raises the question of how financial inclusion relates on financial stability, whether as a substitute or complement. With in other words, whether financial inclusion can improve financial stability or reduce financial stability. Han Melecky (2013: 2) stated that during the period 2006-2009 deposit growth fell by more than 12 percent globally. 2008 global crisis causing deposit growth on average to fall by 15 percent in the country upper middle income. Meanwhile, Azerbaijan, Botswana, Iceland, and Montenegro experienced a drastic drop in deposit growth from 58 percent, 31 percent, 57 percent, and 94 percent (2007) to -2 percent, 1 percent, -1 percent, and -8 percent (2009). Apart from these inclusion factors, the research also includes external factors. These factors include per capita GDP and current assets against deposits and short term funding. (see Morgan and Pontines, 2014; Amatus and Alireza, 2015; Han and Melecky, 2013)

\section{METHOD}

The research model used to see the effect of financial inclusion on financial stability is a modification of the model from Amatus research and Alireza (2015) as follows:

$B Z S i, t=\beta 1+\beta 2 D E P i, t+\beta 3 L O A N i, t+\beta 4 X i, t+\varepsilon i, t(3.1)$

Where:

$B Z S=$ bank $z$-score

DEP = outstanding deposits with commercial banks

LOAN = outstanding loans from commercial banks

$X \quad=$ control variable (LN GDP per capita and current assets on deposits

and short-term funding)

$\varepsilon \quad=$ error term

$i \quad=$ country 
This study focuses on the effect of financial inclusion on stability finance. The data used is panel data. Panel data generally used to support empirical needs. Panel data has an advantage which combines time series and cross section data. Merging this data control the individual aspects of the specific observable and unobservable that may be related to the independent variable. Panel data in this study analyzed countries based on classification income level. This classification is determined by the World Bank (2017). Research it uses 52 high income countries, 44 income countries upper middle class, 42 lower middle income countries, and 24 countries low income. This study measures the effect of financial inclusion on stability financial system based on the classification of the level of state income during the period 2004-2014. This data limitation is due to the limited availability of data and aims to limit the potential for observation in order to focus more on seeing the relationship between financial inclusion and financial stability. The data used in this study are secondary data an annual basis obtained from the World Bank and International databases Monetary Fund (IMF). The data in this study were processed using tools Eviews 6 software.

\section{RESULTS}

\section{Descriptive Statistics}

Statistical descriptive analysis The research object countries were 162 countries during the period 2004-2014. Result descriptive statistics can be seen in Table 1.

Table 1. Descriptive Statistics

\begin{tabular}{lccccc}
\hline & BZS & DEP & LOAN & LGDP & LIQ \\
\hline Mean & 11.46107 & 53.44562 & 51.26808 & 8.441650 & 36.55102 \\
Median & 9.807158 & 39.85514 & 35.42405 & 8.457696 & 31.68323 \\
Maximum & 66.09553 & 795.6413 & 1579.363 & 11.66662 & 162.1736 \\
Minimum & -16.39148 & 2.452362 & 0.973977 & 4.782983 & 0.000000 \\
Std. Dev. & 8.179561 & 58.14758 & 85.81759 & 1.593848 & 19.84083 \\
Skewness & 1.281055 & 6.261106 & 12.01653 & -0.046274 & 1.183337 \\
Kurtosis & 6.034098 & 61.39605 & 185.4943 & 2.011685 & 5.160631 \\
& & & & & 730.4165 \\
Jarque-Bera & 1119.024 & 258451.9 & 2455017 & 72.58607 & 0.000000 \\
Probability & 0.000000 & 0.000000 & 0.000000 & 0.000000 & 62392.59 \\
Sum & 19518.20 & 92941.94 & 89155.20 & 14924.84 & 671581.7 \\
Sum Sq. Dev. & 113872.7 & 5876423 & 12799776 & 4488.802 & 1707 \\
Observations & 1703 & 1739 & 1739 & & 1768 \\
\hline Source: Wortd
\end{tabular}

Source: World Bank and IMF

Table 1 shows that the highest bank z-score of 66.09 percent was achieved by Libya as an upper middle income country in 2011. Meanwhile, the lowest bank z-score of -16.39 was 
achieved by Laos as a lower middle income country in 2004. This This illustrates that Libya in 2011 has a relatively low financial risk, such as the possibility of the banking system going bankrupt is very small, but this did not apply to Laos in 2014. The highest value of outstanding deposits with commercial banks of 795.64 was held by Estonia as a high-income country in 2010. The lowest value of outstanding deposits with commercial banks of 2.45 was held by Congo as a low-income country in 2005. Meanwhile, the highest value of outstanding loans from commercial banks of 1579,363 was held by Estonia as a high-income country in 2009. The lowest value of outstanding loans from commercial banks of 0.97 was held by Congo as a low-income country in 2004. commercial banks and outstanding loans from commercial banks that have been won by high-income countries may be due to the ease of access, availability and use of formal financial services compared to low-income countries. This is evident from the low value of outstanding deposits in commercial banks and outstanding loans from commercial banks that have been earned by low-income countries. The highest LN GDP per capita value of 11.66 was achieved by Czech as a high-income country in 2004. While the lowest LN GDP per capita value was experienced by Burundi as a low-income country in 2004. These results indicate that the high value of foreign GDP per capita followed by a high value of financial inclusiveness as happened in high-income countries. he highest value of current assets against deposits and short-term funding of 162.17 was in Syria as a lower middle income country in 2014. Meanwhile, the lowest value of current assets against deposits and short-term funding of 0.00 went to Iceland as a highincome country in 2004 and 2006.

These results show that Syria is able to meet its short-term obligations and withdraw its deposits which can be paid through current assets due to the high current assets of banks. If this current asset decreases, it could be due to the bank optimizing existing funding sources to finance credit increases and short-term funding (BI, 2012: 34). The high level of current assets can support its asset base. However, low current assets can endanger the health and sustainability of financial institutions. The deposit-receiving institution must plan for the potential for unexpected deposit withdrawals in addition to the liquidity needs of its loan program. If the institution requires greater liquidity, it will increase its cash position or commit to building credit lines that can provide a potential source of liquidity. This path cannot be expected during situations of financial stress. Another way to increase this ratio in the short term is to delay capital spending. Indonesia as a lower middle income country is still dependent on global funding. It is recommended that banks in Indonesia perform stress tests 
and revise their liquidity contingency planning as a step to reduce liquidity risk (Loukoianova et al, 2016).

\section{DISCUSSION}

After going through a series of tests, the results of regression modeling are obtained for the relationship between financial inclusion and financial system stability in countries categorized based on the level of state income. The test results show that countries with different income levels using the fixed effect model have different effects.

Table 2. Relationship of Financial Inclusion and Other Factors to Financial Stability

\begin{tabular}{ccccc}
\hline Variabel & HIC & UMC & LMC & LIC \\
\hline C & $9.596567^{* * *}$ & $6.924170^{* * *}$ & $6.550334^{* * *}$ & $7.354716^{* * *}$ \\
DEP & 0.005534 & 0.019684 & $-0.074271^{* * *}$ & $-0.186947^{* * *}$ \\
LOAN & $-0.006107^{*}$ & $-0.045142^{* * *}$ & 0.005005 & $0.212024^{* * *}$ \\
LGDP & 0.173824 & $0.726099^{* * *}$ & $1.161783^{* * *}$ & 0.247212 \\
LIQ & $0.009725^{* *}$ & $-0.015771^{*}$ & 0.008218 & 0.002189 \\
Durbin Watson & 1.283450 & 1.073211 & 1.122639 & 1.269650 \\
R-Squared & 0.951183 & 0.971952 & 0.953144 & 0.924329 \\
F-Statistic & $176.7793^{* * *}$ & $303.7646^{* * *}$ & $167.7090^{* * *}$ & $94.10190^{* * *}$ \\
\hline
\end{tabular}

Table 2 shows the relationship between outstanding deposits at commercial banks and financial system stability in high and middle income countries and has a positive and insignificant effect. These results were obtained by accepting $\mathrm{H} 0$ on the statistical $\mathrm{t}$ test.

This relationship means that high outstanding deposits will reduce the probability of default. Every 1 percent increase in outstanding deposits will increase financial stability by 0.005 percent in high-income countries, ceteris paribus, and vice versa. Every 1 percent increase outstanding deposits will increase financial stability by 0.01 percent in upper middle income countries, ceteris paribus, and vice versa. The positive relationship between outstanding deposits and financial system stability in high and middle-income countries indicates that the ratio of deposits in commercial banks has diversified. This condition means that there has been an intermediation efficiency in which the financial sector has grown wider with an increase in the number of small savers. This can increase the size and stability base of deposits, reduce bank dependence on non-core funding which tends to be more volatile during crises, and reduce the linkage of procyclical risk. Diversified deposits can minimize deposit withdrawals on a large scale due to systemic shocks. This is because the depositors respond to different shocks so that stability is maintained more resistant to shocks. DemirgucKunt and Klapper (2012) examined the share of people who use deposits in banking (2011), 
and found that the results of the study showed that an increase of 10 percent of people who have access to deposits to banks will reduce deposit withdrawals by 3 to 8 percent. This supports financial inclusion which has a positive effect on financial stability.

The relationship of outstanding loans from commercial banks to the stability of the financial system in high and middle income countries has a negative and significant effect. These results are obtained by rejecting $\mathrm{H} 0$ in the statistical t test at the 10 percent significance level in high-income countries, and at the 1 percent, 5 percent, and 10 percent significance levels in upper middle income countries. This relationship means that low outstanding loans will increase the probability of default. Every 1 percent increase in outstanding loans will reduce financial stability by 0.006 percent in a high-income country, ceteris paribus, and vice versa. Every 1 percent increase in outstanding loans will reduce financial stability by 0.04 percent for lower middle income countries, ceteris paribus, and vice versa. The negative relationship between outstanding loans and financial system stability in high and middle income countries indicates that the lending ratio to commercial banks can lead to erosion of credit standards. This is because financial institutions lower the terms of loans so that they can reach poor households so that the number of borrowers increases. The relationship between foreign GDP per capita and financial system stability in high and low income countries has a positive and insignificant effect. These results were obtained by accepting H0 on the statistical t test. Middle to upper and lower middle income countries have a positive and significant effect. These results are obtained by rejecting $\mathrm{H} 0$ on the t-test statistic at the 1 percent, 5 percent, and 10 percent significance levels.

This relationship means that an increase in GDP per capita decreases the probability of default. Every 1 percent increase in GDP per capita will increase financial stability by 0.001 percent in high-income countries, ceteris paribus, and vice versa. Every 1 percent increase in GDP per capita will increase financial stability by 0.007 percent in upper middle income countries, ceteris paribus, and vice versa. Every 1 percent increase in GDP per capita would increase financial stability by 0.01 percent in lower middle income countries. ceteris paribus, and vice versa. Whereas in middle and upper income countries, every 1 percent increase in GDP per capita will increase financial stability by 0.002 percent in upper middle income countries, ceteris paribus, and vice versa. The positive relationship of GDP per capita to financial system stability between country categories based on income levels indicates that an increase in income is directly proportional to an increase in financial system stability. Allen et al. (2012: 4) suggest that the level of income represented by GDP per capita plays a large 
role in the variation in account penetration around the world. This is where an increase in GDP per capita will lead to an increase in formal account holders in the banking sector.

The effect of the current asset relationship on financial stability between countries of opinion levels can be seen in Table 4.15, where high-income countries have a positive and significant effect. These results were obtained by rejecting $\mathrm{H} 0$ on the t-test statistic at the 5 percent significance level. Low and middle income countries have a positive and insignificant effect. These results were obtained by accepting $\mathrm{H} 0$ on the statistical $t$ test. This relationship means that high current assets will reduce the probability of default. Each 1 percent increase in outstanding deposits will increase financial stability by 0.009 percent in high-income countries, ceteris paribus, and vice versa.

\section{CONCLUSION}

This study shows that there is a relationship between financial inclusion and the stability of the financial system between countries and income levels in the 2000-2014 period. Second, financial inclusion uses a proxy for outstanding deposits at commercial banks and outstanding loans from commercial banks to see the relationship to financial stability as reflected in the Bank z-score variable. Apart from the main independent variables, other factors such as GDP per capita and current assets are also used to assess their relationship to financial stability. The relationship of outstanding deposits at commercial banks to financial system stability in high-income countries (HIC) and upper middle income countries (UMC) has a positive and insignificant effect. This relationship indicates that the deposit ratio at commercial banks has diversified. This condition means that there has been an intermediation efficiency in which the financial sector has grown wider with an increase in the number of small savers. This can increase the size and stability base of deposits, reducing bank dependency on non-core funding, which tends to be more volatile during the crisis, and reduces the associated procyclical risk. Meanwhile, the relationship of outstanding deposits at commercial banks to financial system stability in lower middle income countries (LMC) and low income countries (LIC) has a negative and significant effect. This relationship indicates that the deposit ratio at commercial banks is not yet diversified. This could significantly reduce the resilience of the funding base of banking sector deposits during financial pressures. The relationship of outstanding loans from commercial banks to financial system stability in high-income countries (HIC) and upper middle-income countries (LMC) has a negative and significant effect. This relationship indicates that the ratio of loans to commercial banks can cause erosion of credit standards. This is because financial institutions 
lower the terms of loans so that they can reach poor households so that the number of borrowers increases. However, the results of credit extension have the potential to affect the quality of the credit portfolios of banks and financial institutions.

This situation makes finances fragile (financial fragility) and financial instability. These results indicate the value of financial stability as seen from the opportunity to default or the health value of the financial sector not only influenced by banks but also the securities market. Meanwhile, the relationship of outstanding loans from commercial banks to financial system stability in lower middle income countries (LMC) has a positive and insignificant effect, and in low income countries (LIC) it has a positive and significant effect. This relationship indicates that increasing lending to small companies can reduce the risk of bank credit portfolios such as single borrower portfolios, volatility, and associated financial risks. The relationship between LN GDP per capita and financial system stability in high income countries (HIC) and low income countries (LIC) has a positive and insignificant effect. Meanwhile, upper middle income countries (UMC) and lower middle income countries (LIC) have a positive and significant effect. The positive relationship between an increase in GDP per capita will be in line with an increase in financial stability, because an increase in GDP per capita will lead to an increase in formal account holders in the banking sector. The relationship between current assets and financial stability in high-income countries (HIC) has a positive and significant effect. Lower middle income countries (LMC) and low income countries (LIC) have a positive and insignificant effect. This relationship indicates that an increase in current assets can strengthen stability by encouraging banks to reduce risk on the balance sheet. This increased stability is because banks can liquidate assets during a crisis. Meanwhile, the relationship of current assets to financial stability in upper middle income countries (UMC) has a negative and significant effect. This relationship indicates that an increase in current assets is inversely related to an increase in financial system stability. This occurs because an increase in liabilities for the availability of current assets will reduce the proportion of credit provision, thus hampering the smooth functioning of formal financial institutions.

\section{RECOMMENDATIONS}

The existence of financial inclusion is important because it has a significant effect on financial stability. Therefore, it takes the efforts of various related parties such as the government, central bank, and financial institutions to work together to focus on increasing a country's financial inclusion. Policies, regulations and an enabling environment can 
accelerate increased financial inclusion. Increasing financial inclusion can be carried out in various income level countries and in various ways such as financial education to the public, increasing public financial facilities, improving intermediation and distribution facilities, improving education, and so on.

Financial inclusion can have a positive impact on strengthening financial stability by increasing the diversification of deposits and credit, so that diversification is very necessary for each country between income levels. In addition, easy access to account opening, affordability, mileage, and financial literacy are also needed to reach low-income groups in reducing risks in times of financial stress. What is important in increasing financial inclusion is that regulations are properly regulated so as not to create reputational risks and erosion of credit standards which will lead to a crisis. Efforts to reduce barriers to access both in price and non-price in obtaining financial services and access are at the forefront of achieving the goal of financial inclusion towards financial stability.

\section{REFERENCES}

Ahamed, M. Mostak, and Sushanta Mallick. 2015. "Is Financial Inclusion Good for Bank Stability? International Evidence." 1-11.

Allen, Franklin, Asli Demirguc-Kunt, Leora Klapper, and Maria Soledad Martinez Peria. 2012. "The Foundations of Financial Inclusion: Understanding Ownership and Use of Formal Accounts." World Bank Policy Research Working Paper.

Amatus, Hirwa, and Nasiri Alireza. 2015. "Financial Inclusion and Financial Stability in SubSaharan Africa (SSA)." The International Journal of Social Sciences 36: 39-49.

Anderloni, Luisa, Bernard Bayot, Piotr Bledowski, Malgorzata Iwanicz- Drozdowska, and

Elaine Kempson. 2008. "Financial Services Provision and Prevention of Financial Exclusion." European Commission 1-136.

Asian Institute of Finance. 2013. "Financial Inclusion." Asian Link 1-40.

Baele, Lieven, Olivier De Jonghe, and Rudi Vander Vennet. 2007. "Does the Stock Market Value Bank Diversification?" Journal of Banking and Finance 31: 1999-2023.

Bank for International Settlements. 2010. "Macroprudential Instruments and frameworks: A Stocktaking of Issues and Experiences." CGFS Paper.

Bank Indonesia. 2014. "Booklet Financial Inclusion." Bank Indonesia.

Burton, David R., and Norbert J. Michel. 2016. "Financial Institution: Necessary for Prosperity." The Heritage Foundation Backgrounder 1-14.

Beck, Thorsten. 2016. "Financial Inclusion-Measuring Progress and Progress in Measuring." $1-33$.

Carbo, S., E. P. Gardner, and P. Molyneux. 2005. Financial Exclusion. New York: Palgrave Macmillan.

CGAP-GPFI. 2011. "Global Standard-Setting Bodies and Financial Inclusion for the PoorToward Proportionate Standards and Guidance." GPFI White Paper 1-92. 
Chami, R., C. Fullenkamp, and S. Sharma. 2009. "A Framework for Financial Market Development". IMF Working Paper, July.

Chant, John, Alexandra Lai, Mark Illing, and Fred Daniel. 2003. "Essays on Financial Stability." Technical Report (Bank of Canada) (95): 1-111.

Calderon, Cesar, and Luis Serven. 2011. "Macro-Prudential Policies over the Cycle in Latin America." The World Bank 1-46.

Chiwira, Oscar, Ruramayi Tadu, and Brian Muyambiri. 2013. "Financial Inclusion and Financial Stability: the Important Role of Financial Regulation in Explaining the Relationship. Empirical Review." Journal of Research in International Business and Management 139-149.

Crockett, Andrew. 1997. "Why is Financial Stability a Goal of Public Policy?"

Cull, Robert, Asli Demirguc-Kunt, and Timothy Liman. 2012. "Financial Inclusion and Stability: What Does Research Show?" CGAP 1-4.

Cull, R., T. Ehrbeck, and N. Holle. 2014. "Financial Inclusion and Development: Recent Impact Evidence". CGAP Focus Note, April.

Demirguc-Kunt, Asli, and Leora Klapper. 2012. "Measuring Financial Inclusion The Global Findex Database." Policy Research Working Paper 1-58.

Demirguc-Kunt, Asli, and Leora Klapper. 2013. "Measuring Financial Inclusion: Explaining Variation in Use of Financial Services across and within Countries." Brookings Paper on Economic Activity 279-340.

Demirguc-Kunt, Asli, Thorsten Beck, and Patrict Honohan. 2008. "Finance for All? Policies and Pitfalls in Expanding Access. A World Bank Policy Research Report." A World Bank Policy Research Report.

Deutsche Bundesbank. 2014. "Financial Stability Review."

Diamond, Douglas W., and Philip H. Dybvig. 1983. "Bank Runs, Deposit Insurance, and Liquidity." The Journal of Political Economy 91 (3): 401- 419.

Dornbusch, Rudiger, and Alejandro Reynoso. 1989. "Financial Factors in Economic Development." NBER Working Paper Series.

Dyk, F. 2010. "The new importance of financial stability's 2nd dimension: towards Basel III \& post the recent credit-liquidity crisis". Financial Markets Journal.

Ebrahim, Ahmed, and Iftekar Hasan. 2008. "The Value Relevance of Product Diversification in Commercial Bank." Review of Accounting and Finance 7: 24-37.

Ekberg, Jason, Reet Chowdhuri, Moekti P. Soejachmoen, and Bobby Hermanus. 2015. "Financial Deepening in Indonesia." Oliver Wyman and Mandiri Institute 1-48.

Finacial Action Task Force. 2013. "Anti-Money Laundering and Terrorist Financing Measures and Financial Inclusion." 1-90.

Geršl, A., and J Heřmánek. 2006. "Financial Stability Indicators: advantages and disadvantages of their use in the assessment of the financial system stability". Czech National Bank Financial Stability Review.

Ghosh, Saibal. 2008. "Financial Inclusion and Financial Fragility: An Empirical Note." MPRA Paper 1-11.

Global Partnership for Financial Inclusion. 2012. "Financial Inclusion - A Pathway to Financial Stability? Understanding the Linkages. 
Global Partnership for Financial Inclusion. 2012. "G20 Financial Inclusion Indikators." September.

Goswami, M., and S. Sharma. 2011. "The Development of Local Debt Markets in Asia". IMF Working Paper, June.

Goyal, Rishi, Chris Marsh, Narayanan Raman, Shengzu Wang, and Swarnali Ahmed. 2011. "Financial Deepening and International Monetary Stability." IMF Staff Discussion Note $1-21$.

Gujarati, Damodar. 2003. Basic Econometrics. McGraw-Hill.

Hadad, Muliaman D. 2010. "Developing A Financial Inclusion Strategy: the Case of Indonesia." AFI Global Policy Forum.

Han, Rui, and Martin Melecky. 2015. "Financial Inclusion and Financial Stability: Can Broader Use of Deposits Boost Resilient of Bank Funding." 1-34.

Han, Rui, and Martin Melecky. 2013. "Financial Inclusion for Financial Stability."

Policy Research Working Paper 1-24.

Hannig, Alfred, and Stefan Jansen. 2010. "Financial Inclusion and Financial Stability: Current Policy Issues." ADBI Working Paper Series 1-29.

Hirwa Amatus, Nasiri Alireza. 2015. "Financial Inclusion and Financial Stability in SubSaharan Africa (SSA)." The International Journal of Social Sciences 36 (1): 39-49.

Houben, A., Kakes Jan, and G. Schinasi. 2004. "Toward a Framework for Safeguarding Financial Stability." IMF Working Paper, Juni.

Idiab, Ali Idiab Mohammed, Mohammed Sabri Haron, and Shofian Bin H. Ahmad. 2011. "Commercial Bank and Historical Development." Journal of Applied Sciences Research 1024-1029.

Kahloul, Ines, and Slaheddine Hallara. 2010. "The Impact of Diversification on Firm Performance and Risk: An Empirical Evidence." International Research Journal of Finance and Economics 150-162.

Kempson, Elaine, and Claire Whyley. 1999. "Kept Out or Opted Out?

Understanding and Combating Financial Exclusion." The Policy Press.

Khaitan, Rachit. 2014. "The Role of Financial Inclusion and Financial Deepening." IFMR Finance Foundation.

Khan, H. R. 2011. "Financial Inclusion and Financial Stability : Are They Two Sides of the Same Coin?."

King, R.G. and R. Levine. 1993. "Finance and Growth: Schumpeter Might be Right". Quarterly Journal of Economics. 108 (3): 717-37.

Krugman, P. 1979. "A Model of Balace-of-Payment Crises". Journal of Money, Credit, and Banking. XI.

Leyshon, Andrew, and Nigel Thrift. 1995. "Geographies of Financial Exclusion: Financial Abandoonment in Britain and the United Stated." Wiley Royal Geographical Society (Royal Geographical Society) 20 (3): 312-341.

Loukoinova, Elena, Masahiro Nozaki, Jongsoon Shin, Teresa Curristine, Ken Miyajima, and Giovanni Ugazio. 2016. "Indonesia Selected Issues." IMF Country Report 1-54.

MacFarlane, I. J. 1999. "The Stability of the Financial System." Reserve Bank of Australia Bulletin. 
Malaguti, Maria Chiara. 2015. "Payment System Regulation for Improving Financial Inclusion." Center for Global Development Policy Paper 1-59.

Mankiw, N. Gregory, and Laurence Ball. 2010. Macroeconomics and the Financial System. Worth Publisher.

Melnick, Edward L., Praveen R. Nayyar, Michael L. Pinedo, and Sridhar Seshadri. n.d. "Creating Value in Financial Services." Springer US 2000.

Mishkin, Frederic S. 1990. "Asymmetric Information and Financial Crises: A Historical Persepective." NBER Working Paper Series, Juli.

Mishkin, Frederic S. 1999. "Global Financial Instability: Framework."

Mohan, Rakesh. 2006. "Economic Growth, Financial Deepening, and Financial Inclusion."

Morgan, Peter J., and Victor Pontines. 2014. "Financial Stability and Financial Inclusion." ADBI Working Paper Series 1-16.

Morgan, Peter J., and Yan Zhang. 2015. "Mortgage Lending and Financial Stability in Asia." ADBI Working Paper Series 1-18.

Mulwa, Jonathan Mwau, Daniel Tarus, and David Kosgei. 2015. "Commercial Bank Diversification: A Theorical Survey." International Journal of Research in Management and Business Studies (IJRMBS) 2: 45-49.

Okpara, Godwin Chigozie. 2011. "Financial Inclusion and Financial Stability: A TodaYamamoto Causality Approach." ABSU Journal of Arts, Management, Education, Law and Sosial Sciences (Jamelss) 1.1: 86-100.

Otoritas Jasa Keuangan. 2014. Bank Umum. Jakarta. Accessed May 20, 2017. http://www.ojk.go.id/id/kanal/perbankan/Pages/Bank-Umum.aspx.

Otoritas Jasa Keuangan. 2016. "Master Plan Jasa Sektor Keuangan Indonesia 2015- 2019." Otoritas Jasa Keuangan.

Okuda, Hidenobu. 1990. "Financial Factors in Economic Development: A Study of the Financial Liberalization Policy in the Philippines." The Developing Economies XXVIII: 240-270.

Prasetiantono, Tony. 2017. "Konsolidasi Bank BUMN, Apa Perlunya?" Gatra.

Rajan, R.G., and L. Zingales. 1998. "Financial Dependence and Growth" American Economic Review 88 (3): 559-86.

Sahay, Ratna, Martin Cihak, Papa N'Diaye, Adolfo Barajas, Srobona Mitra, Annette Kyobe, Yen Nian Mooi, and Seyed Reza Yousefi. 2015. "Financial Inclusion: Can it Meet Multiple Macroeconomic Goals?" IMF Staff Discussion Note 1-33.

Santiprabhob, Veerathai. 2016. The Bank of Thailand's financial and monetary policies - the way forward. Bangkok, August 31. Accessed November 1, 2016. http://www.bis.org/review/r160912a.htm.

Sarma, Mandira. 2012. "Index of Financial Inclusion - A Measure of Financial Sector Inclusiveness." Berlin Working Papers on Money, Finance, Trade and Development 134.

Schinasi, Garry J. 2005. "Safeguarding Financial Stability: Theory and Practice." International Monetary Fund. 